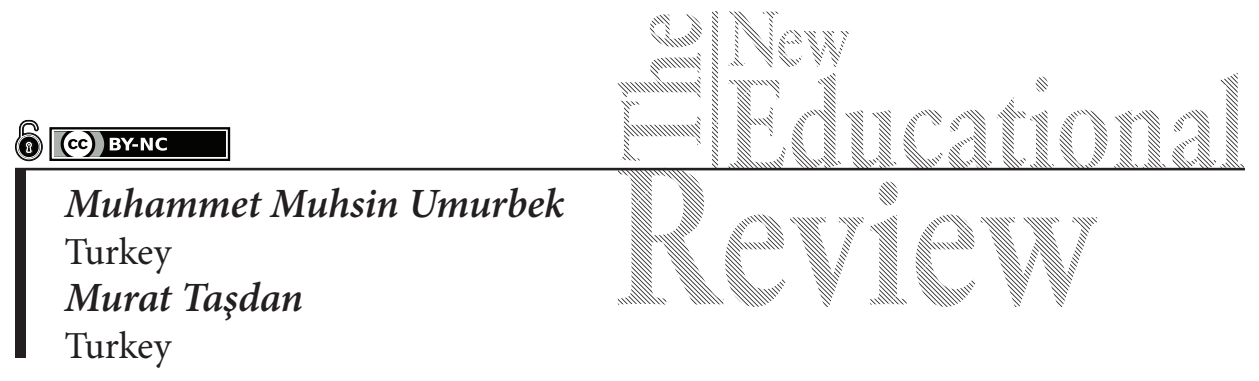

\title{
Identifying the Perceptions of Academic Staff on Internationalization in the Higher Education
}

DOI: $10.15804 /$ tner.2020.59.1.06

\begin{abstract}
The purpose of this study is to identify the perceptions of instructors of internationalization in higher education. The sample of this study consists of 325 faculty members working at four different universities. The data were collected using a scale developed by the researchers. According to findings scale points of the female instructors are better than the male instructors in the foreign language and academic sub-scales. It is seen that perception level of the instructors who were stayed in a foreign country for their education are better than the ones who were not in the academic sub-scale. It is also observed that perceptions of instructors who went to a congress or symposium abroad are better than the ones who did not go to a congress and symposium abroad in the foreign language dimension.
\end{abstract}

Keywords: Globalization, Internationalization in Turkey, Higher Education, Internationalization in Higher Education.

\section{Introduction}

With the development of information and communication technologies, people can easily access information anywhere in the world, which is transforming into a global village. As a result, the boundaries of national economic, cultural, social and educational areas will decline and this process will lead countries, societies, and foundations toward internationalization. The internationalization concept 
has been used in the education sector since the 1980s. In earlier $21^{\text {st }}$ Century, transnational education, borderless education, and cross-border education concepts came into prominence (Knight, 2015). The internationalization process in an educational establishment requires an integrated education, and a comprehensive and miscellaneous action program. Internationalization is a counter-hegemonic, continuous, comprehensive and miscellaneous phenomenon that must be integrated into the process (Schoorman, 2000).

Cantu (2013) stated that instructors who attend international research and education activities, attend international conferences and networks are important for the internationalization of the institution of higher education. However, he stated that there were lacks of coordination, limited economic resources, information administrative policies and procedures, and support staff in this process. In their study, Cantwell and Maldonado (2009) describe internationalization as the response of institutions to globalization. Altbach and Knight (2007) stated that it is important for higher education institutions to engage in international initiatives and to increase the quality of the institution in this regard. Altbach, Reisberg, and Rumbley (2009) stated that internationalization in higher education institutions has turned into economic, technological and scientific trends. Khalid, Ali, Khaleel, Islam and Shu (2017) stated that internationally experienced faculty members are important to the university, that quality assurance and accreditation are important, and that it is necessary to allocate economic resources for internationalization.

\section{Problem of Research}

With the pressure of globalization, the higher education system, like many institutions, is involved in the process of internationalization. The process of internationalization imposes new responsibilities on universities in academic and administrative terms. This study is important in terms of determining the perceptions of instructors about the internationalization process in Turkish higher education in the recent period.

\section{Research Focus}

The main purpose of this study is to determine the perceptions of the instructors of the Kafkas, Ağrı İbrahim Çeçen, Iğdır and Ardahan Universities of internationalization in higher education. Specifically: Do perceptions of the academic staff of internationalization in higher education show a significant difference according to their gender, age, whether they participate in congresses and symposia abroad, whether they have studied abroad, and the university they work in? 


\section{Methodology of Research}

\section{General Background of Research}

The aim of this study is to determine the perceptions of instructors of internationalization in higher education. This research was descriptive and quantitative in method and screening models were used.

\section{Sample of Research}

A two-stage sample was taken in the study. In the first stage, each of the four universities constituting the universe of the study was accepted as a layer and a stratified sample was taken. A proportional sample was taken by taking into account the ratio of the instructors of each university within the universe. In order to provide diversity in terms of variables in the third stage, it was decided, by a simple random sampling method, which measurement tool was to be applied to the instructor at the university. Accordingly, the target population of the study consists of 1923 instructors that are working in Iğdır, Kafkas, Ağrı İbrahim Çeçen, and Ardahan University and the research sample consists of 325 instructors that are chosen from these four universities.

When the distribution of the sample according to age was examined, $71(21.8 \%)$ of the instructors were 25-30 years old, 111 (34.2\%) were 31-36 years, and 67 (20.6\%) 37-42 and 61 (18.8\%) were in the age range of 43 years and older. When the distribution of the sample according to gender was examined, 109 (33.5\%) of the instructors were female and $216(66.5 \%)$ were male. When the participants were examined as to whether they had received education abroad, 87 (26.9\%) answered yes, $236(73 \%)$ answered no. When the participants' participation in international congresses and symposiums was examined, 155 (47.6\%) answered yes and 170 (52.3\%) answered no. When the distribution of the sample by university was examined, 148 (45.5\%) of the instructors are working at Kafkas University, $71(21.8 \%)$ are working at Ağrı İbrahim Çeçen University, 53 (16.3\%) are working at Ardahan University and 53 (16.3\%) are working in Iğdır University.

\section{Instrument and Procedures}

The data collection tool used in the research consists of two different sections. The first section contains introductory information. The answers related to the items in the second section were collected by researchers by the "The Scale of Determining Perceptions of Academic Staff of Internationalization in the Higher Education". On the scale used, each item is answered through a 5-point Likert-type rating scale between (1) Strongly Disagree and (5) Strongly Agree. 
An expert opinion was used for the logical validity of the scale. The validity and reliability analysis of the scale items were determined by applying them on 195 lecturers. According to this, exploratory factor analysis was applied for a validity study of the scale items and analysis was made of the preliminary results. The KMO coefficient was 0.87, and the Bartlett Sphericity test result was significant for exploratory factor analysis of the data set $(p<.05)$. The total variance explained by the scale was calculated as $49.11 \%$. The scale has four factors. The reliability of the scale was determined by Cronbach Alpha internal consistency coefficient. The Cronbach Alpha value of the academic staff's Perception of Internationalization in Higher Education Scale is 0.87 Cronbach alpha values for sub-dimensions, Academic dimension was calculated as 0.94 , education-teaching-management dimension is 0.83 , stakeholder dimension is 0.80 , foreign language is 0.82 .

\section{Results of Research}

Table 1. Arithmetic mean and standard deviation values for academic dimension

\begin{tabular}{llcc}
\hline & \multicolumn{1}{c}{ Scale Item } & $\overline{\mathrm{X}}$ & SD \\
\hline 4 & International studies should be encouraged. & 4.63 & .61 \\
\hline 2 & Taking part in international projects develops academic staff. & 4.59 & .61 \\
\hline 3 & To follow international education standards, develops academic staff. & 4.53 & .63 \\
\hline 8 & $\begin{array}{l}\text { I would like to see better cooperation between foreign universities and ours } \\
\text { in terms of internationalization. }\end{array}$ & 4.47 & .65 \\
\hline 7 & $\begin{array}{l}\text { Academic activities of the university should be encouraged for the academic } \\
\text { staff to work abroad. }\end{array}$ & 4.44 & .65 \\
\hline 12 & International students should be guided to overcome compliance problems. & 4.30 & .71 \\
\hline 16 & It is important for me to speak a foreign language fluently. & 4.42 & .72 \\
\hline 5 & Programs used in education should have international standardization. & 4.39 & .73 \\
\hline 18 & It is important for me to know and learn a different culture. & 4.31 & .73 \\
\hline 1 & It is beneficial for the university to have an academic who studies abroad. & 4.42 & .77 \\
\hline 15 & $\begin{array}{l}\text { Effective accreditation and development of quality assurance policies are } \\
\text { important for internationalization. }\end{array}$ & 4.19 & .73 \\
\hline 6 & $\begin{array}{l}\text { Scientific activities to be organized by the university must be of an interna- } \\
\text { tional standard. }\end{array}$ & 4.34 & .78 \\
\hline 9 & $\begin{array}{l}\text { The exchange of students with universities abroad contributes to the interna- } \\
\text { tionalization of the university. }\end{array}$ & 4.15 & .76 \\
\hline 17 & A mindset of universal thinking for internationalization is important. & 4.32 & .80 \\
\hline 19 & Being in a multicultural campus environment is important to me. & 4.18 & .79 \\
\hline & & & \\
\hline
\end{tabular}




\begin{tabular}{llcc}
\hline \multicolumn{1}{c}{ Scale Item } & $\overline{\mathrm{X}}$ & SD \\
\hline 13 & $\begin{array}{l}\text { For internationalization, students from abroad should be encouraged and } \\
\text { supported. }\end{array}$ & 4.09 & .80 \\
\hline 14 & $\begin{array}{l}\text { The key role of a university in internationalization is activated by the work } \\
\text { of the foreign affairs office. }\end{array}$ & 4.01 & .80 \\
\hline 10 & $\begin{array}{l}\text { Students who come to the university from abroad contribute to internation- } \\
\text { alization. }\end{array}$ & 3.88 & .85 \\
\hline 11 & $\begin{array}{l}\text { Performing scientific activities with students from abroad is a step towards } \\
\text { internationalization. }\end{array}$ & 3.88 & .86 \\
\hline 20 & International students need to be offered part-time job opportunities. & 3.66 & .89 \\
\hline & & &
\end{tabular}

When Table 1 is examined, the academic staff thinks that academic staff should be encouraged to work at the international level $(=4.63)$, and to take part in international projects $(=4.59)$ and it is important to follow international educational standards $(=4.53)$.

Table 2. The values of arithmetic mean and standard deviation related to education-teaching-management dimension

\begin{tabular}{llrc}
\hline & Scale Item & $\overline{\mathrm{X}}$ & SD \\
\hline 24 & The publications of our university follow international standards. & 3.07 & .85 \\
\hline 23 & $\begin{array}{l}\text { The faculty members of our university conduct scientific activities } \\
\text { at the international level. }\end{array}$ & 3.01 & .90 \\
\hline 21 & $\begin{array}{l}\text { The training programs implemented at our university are accredited } \\
\text { using international standards. }\end{array}$ & 3.12 & .98 \\
\hline 25 & Our university organizes scientific activities for internationalization. & 2.96 & .94 \\
\hline 28 & $\begin{array}{l}\text { The management of our university is open to international accredita- } \\
\text { tion. }\end{array}$ & 3.04 & 1.00 \\
\hline 22 & $\begin{array}{l}\text { Our university considers international standards in the choice of aca- } \\
\text { demic staff. }\end{array}$ & 2.71 & 1.06 \\
\hline 26 & Our university is recognized internationally. & 2.38 & .94 \\
\hline 27 & Our university is an international brand. & 2.11 & .91 \\
\hline
\end{tabular}

When Table 2 is examined, it is observed that the teaching programs implemented at the universities are partially considered accredited by international standards (=3.12); and the publications of the universities are partially according to international standards $(=3.07)$. In addition to these, the academic personnel thinks that their universities are not an international brand $(=2.11)$. 
Table 3. Arithmetic mean and standard deviation values of stakeholders

\begin{tabular}{llcc}
\hline \multicolumn{1}{c}{ Scale Item } & $\overline{\mathrm{X}}$ & \multicolumn{1}{c}{ SD } \\
\hline 36 & $\begin{array}{l}\text { The bureaucratic procedures applied in the process of internationalization } \\
\text { are exaggerated. }\end{array}$ & 3.41 & .90 \\
\hline 35 & $\begin{array}{l}\text { The non-govermental and private sector does not contribute to internation- } \\
\text { alization enough. }\end{array}$ & 3.50 & .95 \\
\hline 32 & $\begin{array}{l}\text { The economic resource allocated is not enough for carrying out the interna- } \\
\text { tionalization process effectively. }\end{array}$ & 3.63 & .99 \\
\hline 34 & $\begin{array}{l}\text { There is a problem in terms of coordination between foreign student offices } \\
\text { and police forces, immigration offices, social security institutions, banks, etc. }\end{array}$ & 3.21 & .89 \\
\hline 31 & The incentives for scientific research projects are insufficient. & 3.65 & 1.05 \\
\hline 37 & $\begin{array}{l}\text { Our university is insufficient in organizing activities that will help interna- } \\
\text { tional academic members to adapt. }\end{array}$ & 3.37 & 1.00 \\
\hline 29 & The standards of our university are poor in internationalization. & 3.02 & 1.03 \\
\hline 33 & $\begin{array}{l}\text { The university website is not clear, understandable or guiding for interna- } \\
\text { tional academics. }\end{array}$ & 3.07 & 1.13 \\
\hline 30 & $\begin{array}{l}\text { The institutional culture of our university is not suited to internationaliza- } \\
\text { tion. }\end{array}$ & 3.06 & 1.17 \\
\hline
\end{tabular}

When Table 3 is examined, the teaching staff stated that there are not enough economic resources $(=3.63)$, that the incentives and support for the effective implementation of scientific resources are not adequate $(=3.65)$ and that non-governmental organizations and the private sector do not contribute sufficiently to internationalization $(=3.50)$.

Table 4. Arithmetic mean, and standard deviation values of foreign language dimension

\begin{tabular}{llcc}
\hline \multicolumn{1}{c}{ Scale Item } & $\overline{\mathrm{X}}$ & SD \\
\hline 42 & There should be opportunities for academic staff to learn foreign languages. & 4.43 & .69 \\
\hline 44 & $\begin{array}{l}\text { There should be campus activities where intercultural interaction will be } \\
\text { ensured. }\end{array}$ & 4.19 & .72 \\
\hline 43 & $\begin{array}{l}\text { Activities should be organized to communicate with foreign faculty mem- } \\
\text { bers. }\end{array}$ & 4.13 & .79 \\
\hline 39 & Foreign language education programs should be offered. & 4.12 & .87 \\
\hline 41 & $\begin{array}{l}\text { In internationalization, I think the first step is the knowledge and capability } \\
\text { in a foreign language. }\end{array}$ & 3.74 & 1.00 \\
\hline 38 & The language of globalization is English. & 3.83 & 1.06 \\
\hline 40 & $\begin{array}{l}\text { Announcements on the university campus should be made in different } \\
\text { foreign languages as well as Turkish. }\end{array}$ & 3.61 & 1.05 \\
\hline
\end{tabular}


When Table 4 is examined, the academic staff thinks that they should be able to learn a foreign language and universities should offer opportunities in this respect (=4.43), In addition, they think that the language of globalization is English (= 3.83). Table 5 shows the Mann Whitney $U$ test results of the gender on the scale for determining the perceptions of academic personnel about internationalization in higher education.

Table 5. $U$ test results by gender variable

\begin{tabular}{|c|c|c|c|c|c|c|}
\hline Dimensions & Gender & $\mathrm{N}$ & Row Avg. & $\begin{array}{l}\text { Row } \\
\text { Total }\end{array}$ & $\mathrm{U}$ & $\mathbf{P}$ \\
\hline \multirow{2}{*}{ Academic } & Female & 109 & 177.44 & 19341.51 & \multirow[t]{2}{*}{10197.57} & \multirow[t]{2}{*}{.04} \\
\hline & Male & 216 & 155.76 & 33633.58 & & \\
\hline \multirow{2}{*}{$\begin{array}{l}\text { Education-Training- } \\
\text {-Management }\end{array}$} & Female & 109 & 152.00 & 16568.56 & \multirow[t]{2}{*}{10573.58} & \multirow[t]{2}{*}{.13} \\
\hline & Male & 216 & 168.54 & 36406.59 & & \\
\hline \multirow{2}{*}{ Stakeholders } & Female & 109 & 168.01 & 18313.50 & \multirow[t]{2}{*}{11225.56} & \multirow[t]{2}{*}{.49} \\
\hline & Male & 216 & 160.47 & 34661.54 & & \\
\hline \multirow{2}{*}{ Foreign language } & Female & 109 & 184.91 & 20156 & \multirow[t]{2}{*}{9383} & \multirow[t]{2}{*}{.00} \\
\hline & Male & 216 & 151.96 & 32819 & & \\
\hline
\end{tabular}

There is a significant difference between the male academic staff and the female academic staff in the academic dimension of the scale $(U=10197, p<.05)$. Considering the rank averages, it is understood that international academic perceptions of female instructors are higher than the perceptions of male instructors. In the foreign language dimension of the scale, there was a significant difference between the female lecturers and male instructors' perceptions of international foreign language $(\mathrm{U}=9383, \mathrm{p}<.00)$. When the averages are taken into consideration, it is understood that the female foreign lecturers' perceptions of an international foreign language are higher than males. Table 6 shows the ANOVA test results for age on the scale of the determination of faculty members' perceptions towards internationalization in higher education.

There is a significant difference in terms of age between faculty members' perception of the foreign language dimension of scale $(F(3,306)=2.94, p<.05)$. In other words, the perceptions of the teaching staff about the foreign language dimension differ significantly according to age. According to the results of the Tukey test conducted to find out which groups are responsible for the differences between units, the international foreign language perception of the 25-30 age group (=29.23) was found to be higher than the $37-42$ age group (=27.27) and the 43 age and over group (=27.31). Table 7 shows the independent groups' t-test 
[79]

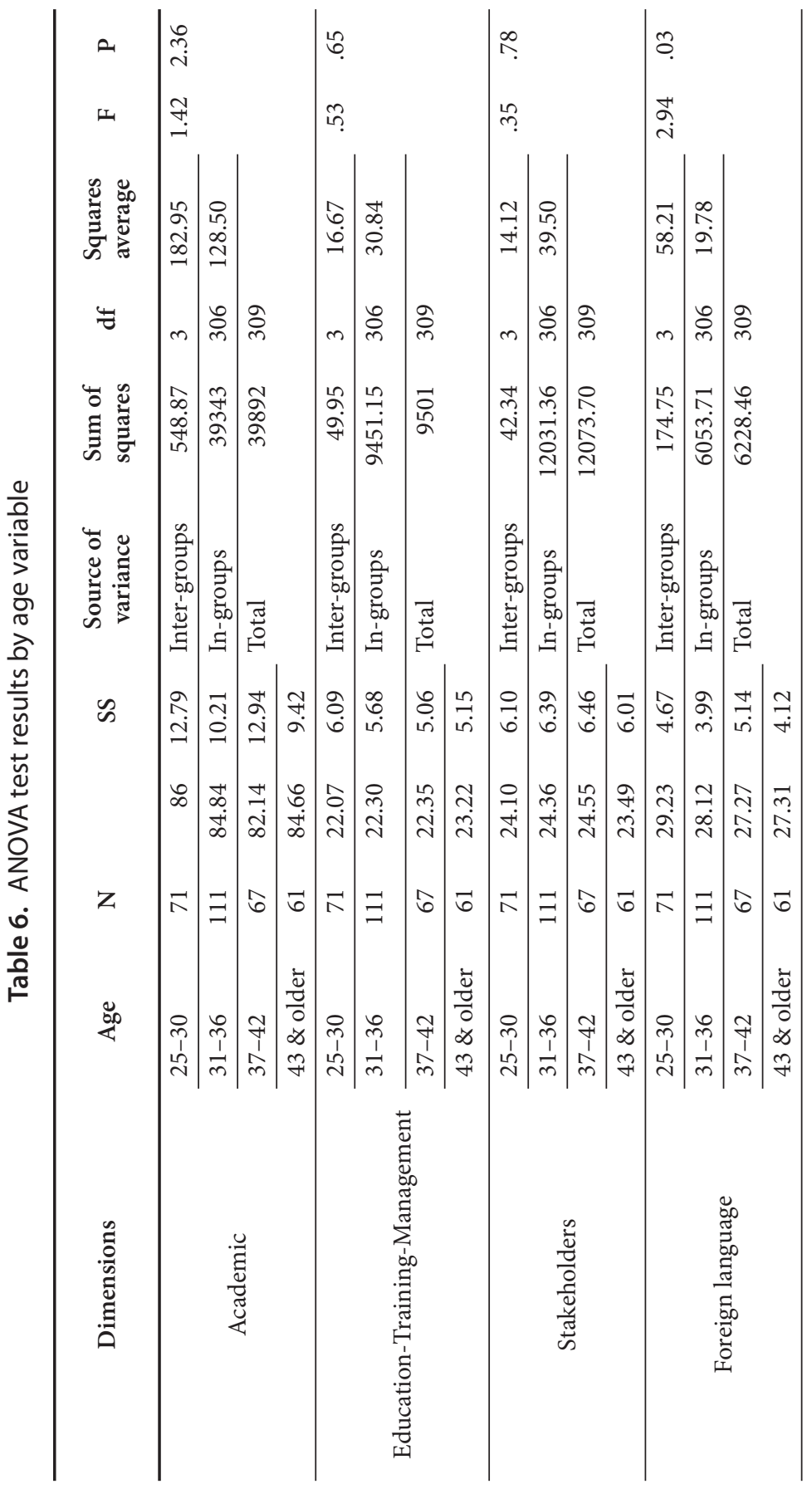


results on the participation of the academic staff in international congresses and symposiums in terms of the scale Perceptions of Internationalization in Higher Education.

Table 7. Results of t-test according to the variable of participation in international congress and symposium

\begin{tabular}{|c|c|c|c|c|c|c|c|}
\hline Dimension & Answer & $\mathrm{N}$ & $\overline{\mathrm{X}}$ & SS & df & $\mathrm{t}$ & $\mathrm{p}$ \\
\hline \multirow{2}{*}{ Academic } & Yes & 155 & 84.25 & 12.44 & \multirow[t]{2}{*}{323} & \multirow[t]{2}{*}{0.176} & \multirow[t]{2}{*}{0.23} \\
\hline & No & 170 & 84.47 & 10.11 & & & \\
\hline \multirow{2}{*}{ Education-Training-Management } & Yes & 155 & 22.63 & 5.72 & \multirow[t]{2}{*}{323} & \multirow[t]{2}{*}{0.41} & \multirow[t]{2}{*}{0.20} \\
\hline & No & 170 & 22.38 & 5.36 & & & \\
\hline \multirow{2}{*}{ Stakeholders } & Yes & 155 & 24.28 & 6.44 & \multirow[t]{2}{*}{323} & \multirow[t]{2}{*}{0.33} & \multirow[t]{2}{*}{0.45} \\
\hline & No & 170 & 24.05 & 6.02 & & & \\
\hline \multirow{2}{*}{ Foreign language } & Yes & 155 & 28.06 & 4.99 & \multirow[t]{2}{*}{323} & \multirow[t]{2}{*}{0.22} & \multirow[t]{2}{*}{0.00} \\
\hline & No & 170 & 27.95 & 4.01 & & & \\
\hline
\end{tabular}

There is a significant difference between the scores of the lecturers' participation in international congresses and symposia and the foreign language dimension scores of the scale $(\mathrm{t}(323)=.22, \mathrm{p}<.05)$. When the averages are examined, it is concluded that the academic staff who attend international congresses and symposiums have higher international foreign language perceptions than those who do not attend. Table 8 shows the results of the Mann Whitney $U$ test for the academic staff's perception of internationalization in higher education in terms of whether they have ever been abroad or not.

Table 8. U test results according to having been abroad

\begin{tabular}{lllllll}
\hline \multicolumn{1}{c}{ Dimension } & Answer & $\mathrm{N}$ & $\begin{array}{r}\text { Row } \\
\text { Avg. }\end{array}$ & Row Total & U & $\mathrm{P}$ \\
\hline \multirow{2}{*}{ Academic } & Yes & 87 & 182.92 & 15912.50 & 8447.50 & .01 \\
\cline { 2 - 6 } & No & 236 & 154.23 & 36413.50 & & \\
\hline \multirow{2}{*}{ Education-Training-Management } & Yes & 87 & 162.03 & 14096.50 & \multirow{2}{*}{10263.50} & .99 \\
\cline { 2 - 6 } Stakeholders & No & 236 & 161.99 & 38229.50 & & \\
\hline \multirow{2}{*}{ Foreign language } & Yes & 87 & 166.50 & 14446.50 & \multirow{2}{*}{9913.50} & .63 \\
\cline { 2 - 6 } & No & 236 & 160.51 & 37879.50 & & \\
\hline
\end{tabular}


In the academic dimension of the scale, there was a significant difference between the academic staff who have had a chance to study abroad and those who have not $(\mathrm{U}=8447.5, \mathrm{p}<.05)$. Considering the rank averages, it is understood that the international academic perceptions about students who are studying abroad are higher than those who are not. Table 9 shows the results of the Kruskal Wallis $\mathrm{H}$ test on perceptions of the academic staff of the internationalization of higher education according to the university currently worked in.

Table 9. Kruskal Wallis $\mathrm{H}$ test results according to the university variable

\begin{tabular}{|c|c|c|c|c|c|c|}
\hline Dimensions & University & $\mathrm{N}$ & $\begin{array}{l}\text { Row } \\
\text { Avg. }\end{array}$ & df & $\mathrm{x}^{2}$ & $\mathrm{p}$ \\
\hline \multirow{4}{*}{ Academic } & Kafkas Univ. & 148 & 168.25 & \multirow[t]{4}{*}{3} & \multirow[t]{4}{*}{2.994} & \multirow[t]{4}{*}{.39} \\
\hline & Iğdır Univ. & 53 & 164.50 & & & \\
\hline & Ardahan Univ. & 53 & 169.24 & & & \\
\hline & Ağrı İbrahim Çeçen Univ. & 71 & 146.11 & & & \\
\hline \multirow{4}{*}{$\begin{array}{l}\text { Education-Train- } \\
\text { ing-Management }\end{array}$} & Kafkas Univ. & 148 & 141.60 & \multirow[t]{4}{*}{3} & \multirow[t]{4}{*}{15.308} & \multirow[t]{4}{*}{.00} \\
\hline & Iğdır Univ. & 53 & 191.41 & & & \\
\hline & Ardahan Univ. & 53 & 181.76 & & & \\
\hline & Ağrı İbrahim Çeçen Univ. & 71 & 172.25 & & & \\
\hline \multirow{4}{*}{ Stakeholders } & Kafkas Univ. & 148 & 180.24 & \multirow[t]{4}{*}{3} & \multirow[t]{4}{*}{11.355} & \multirow[t]{4}{*}{.00} \\
\hline & Iğdır Univ. & 53 & 155.56 & & & \\
\hline & Ardahan Univ. & 53 & 132.62 & & & \\
\hline & Ağrı İbrahim Çeçen Univ. & 71 & 155.30 & & & \\
\hline \multirow{4}{*}{ Foreign language } & Kafkas Univ. & 148 & 170.49 & \multirow[t]{4}{*}{3} & \multirow[t]{4}{*}{4.422} & \multirow[t]{4}{*}{.21} \\
\hline & Iğdır Univ. & 53 & 160.45 & & & \\
\hline & Ardahan Univ. & 53 & 139.54 & & & \\
\hline & Ağrı İbrahim Çeçen Univ. & 71 & 166.80 & & & \\
\hline
\end{tabular}

It is seen that there is a significant difference between the academic staff working in different universities in terms of perceived levels on the scale of education-management $(=15.308, \mathrm{p}<.001)$. It is determined that the international education-teaching-management perceptions of Ardahan University and Iğdır University lecturers are higher than the perceptions of academic staff working in Kafkas University. There is a significant difference in terms of university between the scores of the scale for stakeholders, $(=11.355, \mathrm{p}<.05)$. Kafkas University's perception of international stakeholders was higher than Ardahan University. 


\section{Discussion and Conclusion}

The academic personnel think that the educational programs implemented at the university they work at are not accredited to an international standard, they also think that international standards are not taken into consideration when choosing the academic staff of the university and that scientific publications in the university do not fully comply with international standards. However, Hou (2011), suggested in his study that employing international students and academic staff and establishing campuses/colleges abroad would make the institution more competitive in internationalization. The academic personnel also thinks that the university's internationalization standards are not adequate for the internationalization of the university's corporate culture. On the contrary, Svetlik and Lalic (2016) stated that it is necessary for the institution to increase its international standards and to work in international research and be required to be involved in studies to promote learning studies. The academic personnel thinks that the website of their university is not clear, understandable or guiding for international academic personnel. This runs counter to Ardakani, Yarmohammadian, Abari, and Fathi, (2011) who stated that it is important to organize the web pages of universities in the context of internationalization.

In the research academic staff think that there is a coordination problem between institutions and international student units such as police forces, migration offices, social security institutions, banks, etc. It is also stated that non-governmental organizations and the private sector do not contribute enough to internationalization. In the research, the academic personnel thinks that the university they work in is insufficient in organizing activities that could help the international academic personnel to adapt. The universities should bear in mind the fact that White and Domene (2017) stated that internationalization could be used as a tool to provide diversity on campus and to develop international teaching and research relations. Hayward (2000), in his study, refers to internationalization as the development of instruction according to various cultural views, in order to achieve a position among the societies of the world by integrating an international approach to curricula.

In the research the perception of female academic staff with regards to international academic and foreign language concepts is higher than the perception of male instructors. When the foreign language dimension of the scale is examined, foreign language perception of the 25-30 age group is higher than the age groups $37-42$ and 43 and above. It was determined that the foreign language perceptions 
of the lecturers attending international congresses and symposia were higher than those who did not attend. The academic perceptions of the academic staff who were found to have studied abroad are higher than the perceptions of the instructors who do not have this opportunity. The lecturers think that the language of globalization is English. They believe that the education programs should be presented in a foreign language, the announcements made on the university campus should be done in different foreign languages and that there should be opportunities for academic staff to learn foreign languages and opportunity for intercultural interaction should be provided. This echoes Qiang (2003), who in his study emphasizes that the institution should give importance to foreign language studies.

\section{References}

Altbach, P.G., Reisberg, L., \& Rumbley, L.E. (2009). Trends in global higher education: Tracking an academic revolution. A Report Prepared for the UNESCO 2009 World Conference on Higher Education, 1-278.

Altbach, P.G., \& Knight, J. (2007). The internationalization of higher education: Motivations and realities. Journal of studies in international education, 11(3-4), 290-305.

Ardakani, F., B., Yarmohammadian M., H., Abari, A., A., F. \& Fathi, K. (2011). İnternationalization of higher education systems. Procedia Social and Behavioral Sciences. $15,1690-1695$.

Cantu, P., N. (2013). Three effective strategies of internationalization in American Universities. Journal of International Education and Leadership. 3(3), 1-12.

Cantwell, B., \& Maldonado-Maldonado, A. (2009). Four stories: Confronting contemporary ideas about globalisation and internationalisation in higher education. Globalisation, Societies and Education, 7(3), 289-306. DOI: 10.1080/14767720903166103.

Hayward, F.M. (2000). Internationalization of US. Higher education: Preliminary Status Report. Washington, DC 20055-0191.

Hou, A.Y.C. (2011). Quality assurance at a distance: international accreditation in Taiwan higher education. Higher Education, 61(2), 179-191.

Khalid, J., Ali, A.J., Khaleel, M., \& Islam, M.S. (2017). Towards Global Knowledge Society; A SWOT Analysis of Higher Education of Pakistan in Context of Internationalization. Journal of Business, 2(2), 08-15.

Knight, J. (2015). Updated definition of internationalization. International higher education. (33). 2-3. DOİ:10.6017/ihe.2003.33.7391.

Qiang, Z. (2003). Internationalization of higher education: towards a conceptual framework. Policy Futures in Education, 1(2), 248-270.

Schoorman, D. (2000). What really do we mean by internationalization? Contemporary Education, 71(4), 5. 
Svetlik, I. \& Lalić, A.B. (2016) The impact of the internationalisation of higher education on academic staff development - the case of Slovenian public universities, Studies in Higher Education, 41(2), 364-380, DOI: 10.1080/03075079.2014.942266.

White, M. \& Domene, J. (2017). Education in the context of internationalization, immigration, and forced migration: Introduction to the Special Issue. Antistasis, 6(2). 1-4. 